WPS3926

\title{
AN ANALYSIS OF MONEY'S WORTH RATIOS IN CHILE
}

\author{
Craig Thorburn, Roberto Rocha, and Marco Morales ${ }^{1}$
}

\begin{abstract}
Empirical analyses of annuities markets have been limited to a few developed countries and restricted by data limitations. Chile provides excellent conditions for research on annuities due to the depth of its market and the availability of data. The paper utilizes an extensive dataset on individual annuities to examine econometrically a measure of market performance - money's worth ratios (MWRs), or the ratio of the expected present value of annuity payments to the premium. The results show that annuitants in Chile have generally got a good deal for their premiums, as indicated by MWRs higher than one and also higher than those estimated for other countries. The difference between Chile and other countries is striking considering that annuities in Chile are indexed to prices. The wide range of indexed instruments in Chile, allowing providers to hedge their risks while extracting higher returns, helps explain the difference. The high degree of market competition has also contributed to this outcome. Efforts to improve market transparency through a new electronic quotation system have decreased the dispersion of MWRs. Finally, MWRs tend to decrease for contracts with longer durations, reflecting pricing for higher longevity and reinvestment risks. These results are consistent with separate research on the annuity rate, and indicate the need to ensure competition and market transparency, as well as to develop appropriate financial instruments for providers in order to ensure good outcomes for annuitants.
\end{abstract}

\section{World Bank Policy Research Working Paper 3926, May 2006}

The Policy Research Working Paper Series disseminates the findings of work in progress to encourage the exchange of ideas about development issues. An objective of the series is to get the findings out quickly, even if the presentations are less than fully polished. The papers carry the names of the authors and should be cited accordingly. The findings, interpretations, and conclusions expressed in this paper are entirely those of the authors. They do not necessarily represent the view of the World Bank, its Executive Directors, or the countries they represent. Policy Research Working Papers are available online at http://econ.worldbank.org.

\footnotetext{
${ }^{1}$ Craig Thorburn and Roberto Rocha are at the Operations Policy Department of the World Bank and Marco Morales is at the Diego Portales University in Santiago de Chile. This paper was derived from a comprehensive report of the Chilean market for retirement products, coordinated by Roberto Rocha and Craig Thorburn (2006), and part of a broader World Bank project on the payout phase of private pension systems involving several country studies. The authors are grateful to Gregorio Impavido for valuable inputs in the early stages of the research. The authors are also grateful to Eduardo Walker, Dimitri Vittas, Augusto de la Torre, Augusto Iglesias, Guillermo Martinez, Solange Berstein, Guillermo Larrain, Alejandro Ferreiro, Ernesto Rios, Osvaldo Macias, Richard Hinz, and several industry participants for comments on earlier versions of the paper.
} 


\section{Introduction}

The increased involvement of the private sector in pension provision has led to a substantial volume of research on the structure, performance, and regulation of private pension funds, both in developed and emerging countries. However, there are fewer empirical analyses of the payout phase, which involves the transformation of the final balance into flows of retirement income through instruments such as annuities and phased withdrawals (PWs) and a greater role of the insurance sector.

Most empirical studies on the payout phase involve the computation of money's worth ratios, or the ratio of the expected present value of annuity payouts to the annuity premium. Money's worth ratios (MWRs) provide a useful measure of the performance of annuities markets and also allow researchers to investigate the presence of adverse selection in these markets. However, this empirical research is usually restricted to a relatively narrow number of developed countries, and based on a relatively limited number of annuity quotations, which prevents a more in-depth statistical analysis of the determinants of MWRs.

The absence of more in-depth analyses of the payout phase is cause for concern, as many countries have implemented pension reforms that have included the introduction of mandatory private pillars, and will need to face the payout phase in the near future. Policy-makers in these countries would benefit from analyses that provide more insights and inputs to the design of a sound regulatory framework for products and intermediaries. This is particularly the case for annuities, products that involve very long contracts and complex risks.

Chile provides one of the most relevant experiences for countries that have reformed their pension systems and that face the challenge of developing markets for annuities and phased withdrawals. This is due to its well-known pension reform of 1981, which involved a move from a public pay-as-you-go (PAYG) system to a fully-funded (FF) system operated by the private sector. At the start of its pension reform in the early 1980s, Chile was a middle-income country without a pension industry, an incipient insurance sector, little regulatory and supervisory capacity, and undeveloped capital markets. Twenty-five years later Chile had reasonably developed markets for retirement products, evidenced by about 320,000 annuity policies and 200,000 PWs, and 17 life insurance companies providing annuities and managing assets of 20 percent of GDP.

This paper provides a detailed examination of MWRs in Chile, during the 1999-2005 period. The existence of extensive data on individual annuity policies, including information on individual annuitant characteristics and types of annuities, allows not only the computation of a large number of MWRs, but also an analysis of their main determinants. This analysis provides important insights on the performance of the annuities market and inputs to the formulation of appropriate policies in this area. 
The paper is structured as follows. The second section provides an overview of the Chilean annuity market. The third section discusses a number of methodological issues that arise in the computation of MWRs, including formulas, mortality tables and discount rates. The fourth section examines the data used for the computation of MWRs, stressing the use of data on actual annuity sales rather than quoted annuities. The fifth section presents the results, which include an examination of average MWRs across main classes of annuities, as well as regressions of these ratios against individual annuitant characteristics such as age, gender, and premiums, as well as types of annuities. The sixth section compares MWRs for Chile with those produced by other researchers for Chile and other countries. Finally, the last section summarizes the main findings and discusses some policy implications.

\section{A Brief Overview of the Chilean Annuity Market ${ }^{2}$}

The Chilean annuities market has its origins in the well-known pension reform implemented in 1981, which entailed the replacement of the PAYG system by an FF system with individual accounts managed by private pension fund administrators (Administradoras de Fondos de Pensiones - AFPs). The transition from the old to the new pension system is virtually completed - by 2004 nearly 97 percent of contributors were enrolled in the new pension system. The number of active contributors is 3.5 million workers, or the equivalent to about 55 percent of the labor force. This is a low coverage ratio by average OECD standards but a high ratio by comparison with middle income countries in Latin America and other regions.

Workers enrolled in the new pension system can retire at the normal retirement age of 65 and 60 for men and women, respectively. They can also retire earlier if they meet specific conditions. Until 2004 workers could retire if their accumulated savings could generate a pension equal to at least 110 percent of the minimum pension guarantee and 50 percent of their average real wage in the period of 10 years preceding retirement. The government has discretion over the level of the minimum pension guarantee, but has usually set it around 25 percent of the average economy-wide wage. A new Pension Law passed by Congress in 2004 raised these requirements to 150 percent of the minimum pension guarantee and 70 percent of the average real wage.

At the end of 2004 more than 500,000 workers had retired under the new system, as shown in Table 1. Since access to lump-sums is restricted, retiring workers can basically choose between life annuities, phased withdrawals (PWs), or temporary withdrawals (TWs), which are essentially phased withdrawals combined with a deferred annuity. The number of retirees choosing annuities has increased considerably in the past 20 years. As shown in Table 1, only 3 percent of the stock of pensioners had chosen annuities in 1985, while in 2004 this percentage had increased to more than 60 percent. This number implies one of the highest rates of annuitization in the world.

Annuities in Chile are strictly regulated and until 2004 the range of choices was relatively limited. All annuities are fixed and indexed to prices. Married males have to buy joint

${ }^{2}$ Rocha and Thorburn (2006) provide a detailed analysis of Chile’s market for retirement products. 
annuities, thus providing longevity risk insurance to both themselves and their spouses. A surviving spouse receives 60 per cent of the payment after the death of the main beneficiary. Retiring workers have the option of buying guaranteed annuities, which start at a lower level, but maintain payments at this level (i.e., without the 40 percent reduction) during the guaranteed period, even after their death or the death of their spouse. This type of annuity has proved very popular in Chile, as it allows more protection to the spouse and some element of bequest. The new Pension Law passed in 2004 has introduced some additional options, especially variable annuities. The new Law also introduced an innovative electronic quotation system, designed to enhance market transparency and reduce the influence of brokers in the selection of retirement products and intermediaries.

Table 1: Breakdown of Stock of Pensions, by Type of Instrument, 1985-2004

\begin{tabular}{c|c|cccccc}
\hline Year & Total & \multicolumn{2}{|c}{ PWs } & \multicolumn{2}{c}{ TWs } & \multicolumn{2}{c}{ Annuities } \\
& & Number & \% of Total & Number & \% of Total & Number & \% of Total \\
\hline 1985 & 7,609 & 7,373 & 96.8 & - & 0.0 & 236 & 3.2 \\
1990 & 57,119 & 36,696 & 64.2 & 148 & 0.3 & 20,275 & 35.5 \\
1995 & 190,400 & 98,699 & 51.8 & 6,803 & 3.6 & 84,898 & 44.6 \\
2000 & 343,965 & 147,532 & 42.9 & 6,632 & 1.9 & 189,801 & 55.2 \\
2004 & 520,793 & 196,242 & 37.7 & 6,193 & 1.2 & 318,358 & 61.1 \\
\hline
\end{tabular}

Source: SAFP

Annuity providers in Chile have had access to a wide range of fixed income instruments with long durations and indexed to prices, including privately-issued instruments offering higher yields than government bonds. This access has allowed providers to hedge the complex risks associated with annuities reasonably well. Providers are also allowed to price annuities freely, and to differentiate risk according to basic annuitant characteristics, such as age, gender, and income.

The growth of the number of annuitants has led to a rapid expansion of the insurance sector, with total insurance assets growing from 5 percent of GDP in the mid-1980s to 20 percent of GDP in 2004. The large volume of pension assets - more than 60 percent of GDP - indicates that insurance assets should continue growing strongly in coming years, as these are pension accounts that will need to be converted into annuities and PWs at retirement.

The fast increase in the number of annuity contracts attracted new entrants to the life insurance market, increasing the total number of life insurance companies to 34 by the late 1990s, 23 of which were providing annuities. As shown in Figure 1 and Figure 2, the increase in the number of participants in the 1990s led to a continuous decrease in concentration ratios, quite in contrast with the pension fund sector. The access to a wide range of financial instruments allowing providers to hedge the risk of their liabilities and the high degree of competition in the annuities market has generally resulted in good outcomes for annuitants, as indicated by the high money's worth ratios shown in the following sections. 
In recent years some life insurance companies have decided to exit the annuities segment of the life insurance market, discouraged by the very intensive degree of competition, the thin intermediation spreads and the relatively low returns on equity. These factors have resulted in some increase in concentration ratios. However, the insurance sector in Chile remains much more competitive than the pension fund sector, whether measured by the number of participants or concentration ratios, as shown in Figures 1 and 2.

\section{Figure 1}

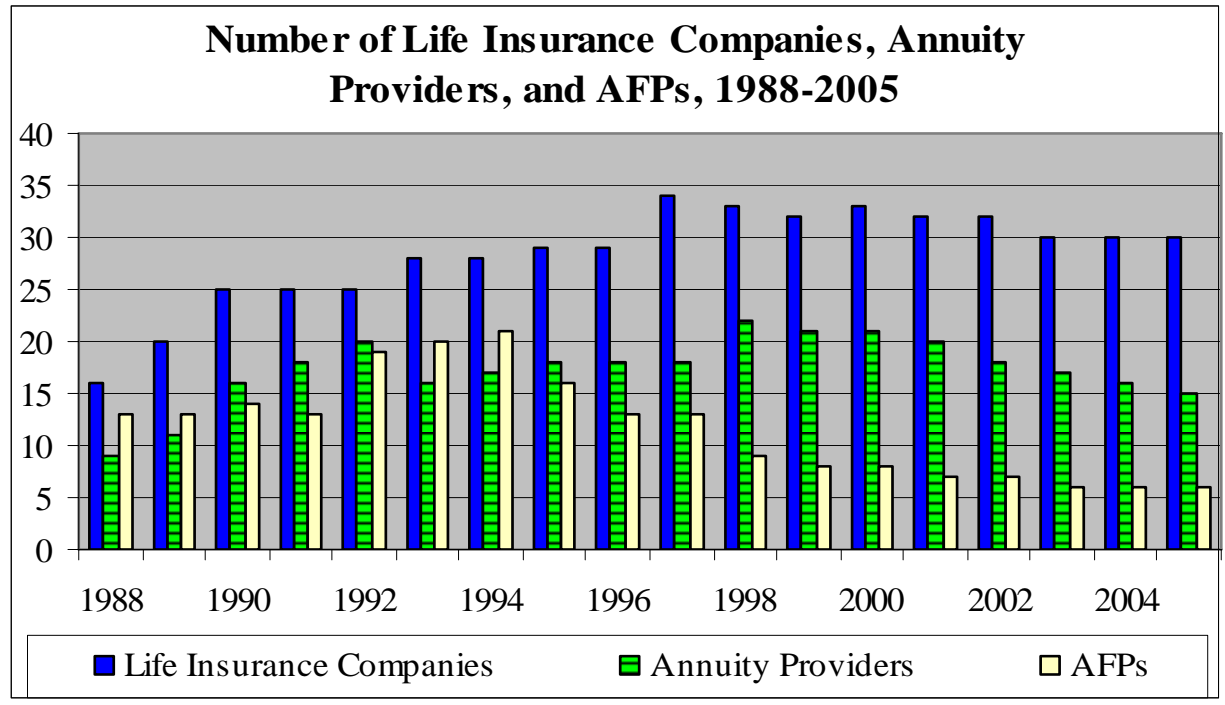

Figure 2

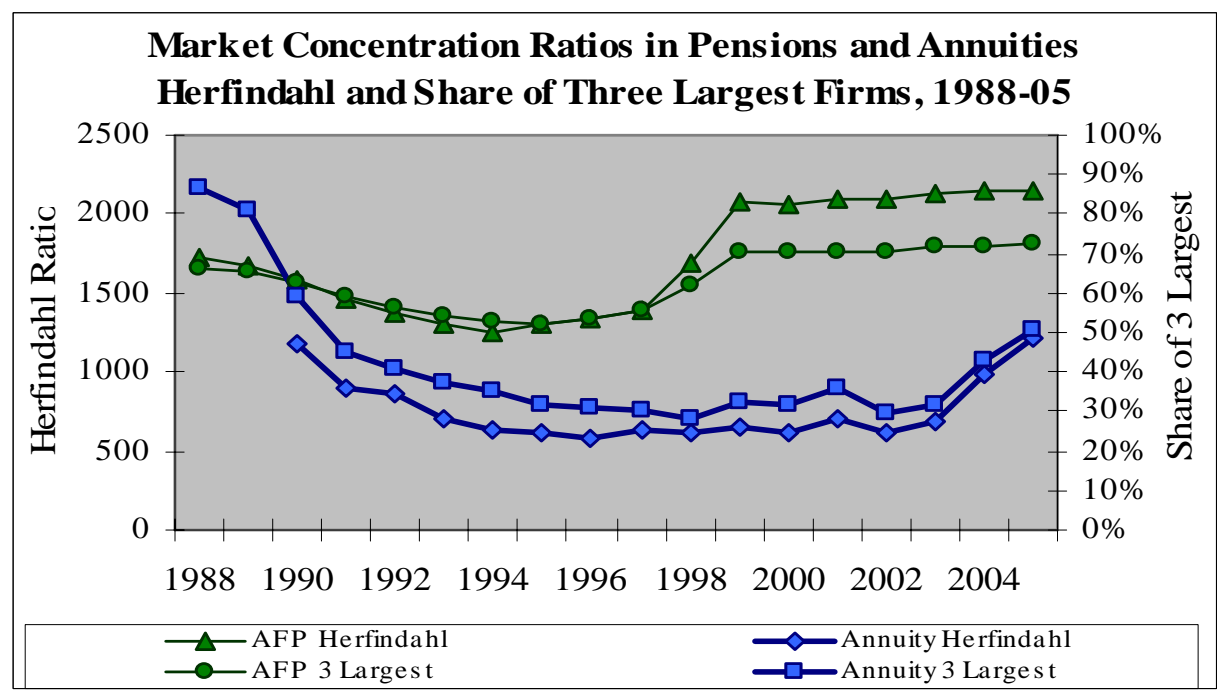




\section{Methodology for Computing MWRs}

\subsection{MWR Formulas}

The money's worth ratio is an indication of the value provided to the customer in an annuity product. It is defined as the ratio of the expected value of the benefits payable under the contract to the premium paid. A mortality table and an interest rate yield curve are required to determine the value of the benefits for this process.

The calculation of the value of the payment streams in Chile requires that the features of the products be reflected. In particular, it is necessary to allow for the fact that annuities are issued as either joint or single life, that some are issued with a period of initial deferment, and that some are issued with the payment guaranteed for a defined period regardless of survivorship. A small funeral benefit of UF15 is provided as part of the annuity purchase and is also considered in the calculations. Benefits for dependent children have not been considered, because it is not possible to identify from the data the cases where these benefits would be payable. However, the effect of ignoring these dependent benefits is small, not affecting the conclusions or international comparisons.

As a result of these characteristics, the MWR formula for a single life annuity issued to a person aged $x$ is as set out in Equation (1):

$$
M W R=\frac{\left(A \sum_{t=d+1}^{12(\omega-x)} \frac{{ }_{t} p_{x}}{\left(1+i_{t}\right)^{t}}\right)+V}{P}
$$

where:

MWR is the Money's Worth Ratio;

A is the monthly annuity payment in UF;

$W \quad$ is the ultimate age in the mortality table, the oldest age assumed where there are not remaining surviving lives;

${ }_{t} p_{x} \quad$ is the probability that a life aged $x$ at commencement is still alive at time t, that is after $t$ months in this case, at age $x+(t / 12)$. Note that, in the case of a guaranteed period then ${ }_{t} p_{x}$ is set equal to 1 for the period that the guarantee is in force;

$d \quad$ is the number of months deferment in the case of a deferred annuity;

$i_{t} \quad$ is the interest rate used to discount payments at time $t$, obtained from the term structure of interest rates;

$V \quad$ is the value of the funeral benefit; and

$P \quad$ is the single premium payment made for the contract.

The first term between parentheses in the numerator is the expected present value of future annuity payments. The division of this term by the premium is the MWR formula usually used in empirical research in other countries. Equation (1) also includes the expected present value of the small funeral benefit $V$ because it is part of the annuity benefit in the Chilean case. 
The joint life formula contains the reversion of the annuity to the second beneficiary (typically the spouse) at a lower level (60 percent), and the survivorship of two lives determining the annuity payment. If the principal beneficiary is noted with symbols as above, and the reversionary beneficiary is noted with the same symbols but with a ' $\wedge$ ' mark and is aged $y$ at commencement of the annuity, then the formula is as set out in equation (2). Note that the probability term in the numerator would be set to 1 during the period where annuity payments are guaranteed.

$$
M W R=\frac{\left(A \sum_{t=d+1}^{12(\omega-x)} \frac{{ }_{t} p_{x}+0.6\left(\left(1-{ }_{t} p_{x}\right)_{t} \hat{p}_{y}\right)}{\left(1+i_{t}\right)^{t}}\right)+V}{P}
$$

Note that all annuities in Chile are quoted in Unidades de Fomento (UF), a unit of account indexed to consumer prices and widely used in financial contracts. In this analysis all values are expressed in UF and should be interpreted accordingly when making comparisons with other countries. ${ }^{3}$

\subsection{Mortality Tables}

Most empirical studies estimate MWRs with two mortality tables, one reflecting the mortality of the general population and the other reflecting the mortality of the smaller annuitant population. These are necessarily cohort tables, constructed either by incorporating existing projections of future mortality for each cohort, or by estimating future mortality improvements and applying them to period tables. ${ }^{4}$ The difference between the estimated MWRs using the general and the annuitant population assumptions is frequently interpreted as the effect of adverse selection.

In the case of Chile, there was no mortality table for the population that is updated and reliable at the time of writing, but three tables have been constructed for the annuities market. The first of these tables, known as RV-85, is a period table that was developed when the annuity system started and there were few annuities in force. The table purports to represent the period experience of annuitant mortality at the time it was developed, but was partly constructed by making adjustments to mortality data from other countries. The RV-85 was developed for regulatory purposes, and served until recently as the basis for the determination of phased withdrawal (PW) payments and the calculation of technical reserves for annuity providers.

The second table, referred to as RV-98, is a period table based on more extensive Chilean annuitant mortality data collected between 1995 and 1997. The table represents an improvement over the RV-85, by including more information on the mortality of the Chilean annuitant population. However, while the male tables were mostly determined from the data, the female tables largely impute the observed rate of change between the

\footnotetext{
3 The Pension Law approved in 2004 has allowed other types of annuities, but all the MWRs presented in this report refer to annuities fixed in UFs, i.e., annuities indexed to prices.

${ }^{4}$ See, e.g., Brown et al (2001), and James, Song and Vittas (2003).
} 
RV-85 and RV-98 tables for males, to the RV-85 table for females. As a result, the rate of mortality improvement is essentially the same for both sexes.

Finally, the third table, referred to as RV-04, is a period table based on Chilean annuitant mortality data collected between 1995 and 2003. The RV-04 is more representative of the Chilean annuitant population than its two predecessors and has recently been adopted for all regulatory purposes. Among several of its positive features, both male and female tables were developed separately, and the representative version of the table passed all the standard consistency tests comfortably. ${ }^{5}$

However, these recently constructed tables still have some shortcomings that need to be considered. Because there are fewer annuitants at older ages, data was included from the previous scheme. This implies that the mortality rates at older ages may not be as representative of annuitants as the earlier ages, and rather reflect the mortality of retirees under the old system. Rates were updated to 2004 using the national statistical agency's assumed age-specific improvement rates for the population. The RV-04 table was selected for the computation of MWRs because it is the most representative of the current annuity population. The table was adjusted to the relevant year of issue of each annuity using the same approach adopted in the official table and the same rates.

As shown in Table 2, there are significant differences in the shape of the three mortality tables. Mortality rates in the RV-98 and RV-04 are systematically and substantially lower than those in the RV-85. Male mortality rates in the RV-04 are lower than those in RV98 for intermediate ages, but higher at some younger and older ages. Female mortality rates, however, are substantially lower in the RV-04. As noted above, the earlier (RV-85 and RV-98) tables for females are constructed more subjectively than the RV-04 tables for both sexes and the RV-98 table for males. Whilst the shape and level of the mortality tables is still a matter for some debate in Chile, the RV-04 table seems to be the most scientific and robust for both sexes.

Each of these three tables is published as a period table, requiring adjustments in order to convert them into cohort tables. Cohort results were initially developed using two alternatives, namely, national population projection rates, and the rates of improvement between the RV-85 and the RV-04 tables. The first method was ultimately judged as superior and has been adopted here. The basic reason was the high degree of arbitrariness involved in the construction of the RV-85 table. In particular, it is clear that the female improvement rates derived from these tables continue to be open to greater uncertainty and are well above the observed and assumed population estimates.

\footnotetext{
${ }^{5} \mathrm{~A}$ standard battery of statistical tests is set out in Benjamin and Pollard (2001) and has been applied to the RV-04 tables separately for male and female tables. In the case of each test, the representative table used in these calculations is found to pass the test - that is, the table reflects the underlying mortality experience.
} 
Table 2: Levels and Changes in Mortality Rates

\begin{tabular}{|c|c|c|c|c|c|c|c|c|c|c|}
\hline \multirow{3}{*}{\begin{tabular}{c} 
品 \\
\cline { 2 - 13 }
\end{tabular}} & \multicolumn{3}{|c|}{ Period Tables } & \multicolumn{1}{|c|}{$\begin{array}{c}\text { Improvement Rates } \\
\text { for Cohort Tables }\end{array}$} & \multicolumn{2}{c|}{ Period Tables } & $\begin{array}{c}\text { Improvement Rates } \\
\text { for Cohort Tables }\end{array}$ \\
\cline { 2 - 13 } & RV85 & RV98 & $\begin{array}{c}\text { RV04 } \\
\text { unbiased }\end{array}$ & $\begin{array}{c}\text { Pop. } \\
\text { Projection }\end{array}$ & $\begin{array}{c}\text { RV04/ } \\
\text { RV85 }\end{array}$ & RV85 & RV98 & $\begin{array}{c}\text { RV04 } \\
\text { unbiased }\end{array}$ & $\begin{array}{c}\text { Pop. } \\
\text { Projection }\end{array}$ & $\begin{array}{c}\text { RV04/ } \\
\text { RV85 }\end{array}$ \\
\hline 50 & 0.0054 & 0.0044 & 0.0044 & $1.40 \%$ & $1.44 \%$ & 0.0027 & 0.0022 & 0.0015 & $1.40 \%$ & $3.91 \%$ \\
\hline 55 & 0.0082 & 0.0059 & 0.0058 & $1.40 \%$ & $2.39 \%$ & 0.0042 & 0.0030 & 0.0024 & $1.50 \%$ & $4.04 \%$ \\
\hline 60 & 0.0124 & 0.0089 & 0.0091 & $1.50 \%$ & $2.23 \%$ & 0.0066 & 0.0047 & 0.0035 & $1.40 \%$ & $4.46 \%$ \\
\hline 65 & 0.0189 & 0.0146 & 0.0139 & $1.50 \%$ & $2.16 \%$ & 0.0104 & 0.0080 & 0.0049 & $1.40 \%$ & $5.22 \%$ \\
\hline 70 & 0.0288 & 0.0239 & 0.0219 & $1.50 \%$ & $1.94 \%$ & 0.0165 & 0.0137 & 0.0072 & $1.50 \%$ & $5.76 \%$ \\
\hline 75 & 0.0447 & 0.0384 & 0.0356 & $1.50 \%$ & $1.61 \%$ & 0.0272 & 0.0237 & 0.0127 & $1.30 \%$ & $5.30 \%$ \\
\hline 80 & 0.0693 & 0.0624 & 0.0593 & $1.40 \%$ & $1.11 \%$ & 0.0451 & 0.0401 & 0.0261 & $1.20 \%$ & $3.84 \%$ \\
\hline 85 & 0.1070 & 0.0963 & 0.0971 & $1.20 \%$ & $0.69 \%$ & 0.0750 & 0.0680 & 0.0523 & $1.20 \%$ & $2.54 \%$ \\
\hline 90 & 0.1636 & 0.1472 & 0.1511 & $1.20 \%$ & $0.56 \%$ & 0.1238 & 0.1115 & 0.0942 & $1.20 \%$ & $1.94 \%$ \\
\hline 95 & 0.2459 & 0.2213 & 0.2219 & $1.20 \%$ & $0.73 \%$ & 0.2013 & 0.1812 & 0.1527 & $1.20 \%$ & $1.95 \%$ \\
\hline 100 & 0.3600 & 0.3240 & 0.3097 & $1.20 \%$ & $1.07 \%$ & 0.3180 & 0.2862 & 0.2283 & $1.20 \%$ & $2.34 \%$ \\
\hline 105 & 0.5064 & 0.4557 & 0.4261 & $1.20 \%$ & $1.23 \%$ & 0.4792 & 0.4313 & 0.3328 & $1.20 \%$ & $2.57 \%$ \\
\hline 110 & 1.0000 & 1.0000 & 1.0000 & $1.20 \%$ & $0.00 \%$ & 1.0000 & 1.0000 & 1.0000 & $1.20 \%$ & $0.00 \%$ \\
\hline
\end{tabular}

Source: SVS and Staff Calculations

Note: The values for the RV-04 tables shown here are not updated to any particular year, i.e., are representative of mortality centered around 1999.

\subsection{Discount Rates}

In line with most other studies, the computation of MWRs is performed with two alternative discount rates, the interest rate on government or central bank bonds and the interest rate on corporate bonds. The MWR computed with the first rate is frequently considered to be the most meaningful to the average customer, as it excludes risk and reflects its opportunity cost more accurately. It is also used to facilitate comparisons across countries. The alternative discount rate is also computed, as it may reflect more appropriately the opportunity cost for some consumers, and because it is more relevant from the point of view of the provider.

The risk-free discount rates were obtained by the yield curve of 20 year indexed central bank bonds (the PRC-20) in March of 1999, 2002, 2003, 2004 and 2005 - as indicated below, the annuity sample consists of all annuities sold in those five months. ${ }^{6}$ The yield curve for those five months was provided by the Central Bank of Chile, consisting of daily estimates of the zero coupon yield curve for maturities ranging from one month to 20 years. These curves were originally generated using interpolation and smoothing approaches developed by the RiskAmerica company, drawing on what is usually a limited number of trades on any given day in the PRC-20. The Central Bank of Chile makes some additional adjustments, based on the transactions of similar debt instruments.

\footnotetext{
${ }^{6}$ March was the month selected to allow comparisons with estimates of MWRs by other researchers.
} 
The yield curve utilized in the MWR computations was the average of the daily yield curves in March of each of those five years. ${ }^{7}$

The second technical limitation that had to be addressed was the absence of debt instruments with sufficiently long duration. Although Chile has had more success in lengthening the maturities of debt instruments than most other emerging countries, the yield curve still does not cover the possible life of annuity payments. Consistent with the approach taken by James, Iglesias, and Martinez (2005), the yield curve was assumed to be flat after 20 years. This solution seems reasonable, as the yield curve in the months examined is essentially flat in the durations from 15 to 20 years. Finally, the alternative discount rate was constructed by adding the actual spread of corporate bonds over the PRC-20 for each of the periods 2002 - 2004. In March of 2002, 2003 and 2004, these spreads were $1.7,2.5$ and 1.4 percent, respectively.

\section{The Data}

Most empirical studies generally involve the collection of several annuity quotations, the computation of averages for different categories, and the calculation of MWRs for these categories (e.g., single annuities by sex and age, joint annuities, guaranteed annuities). The high level of disclosure in Chile includes information on every individual annuity sold. As a result, it is possible to compute MWRs for all these categories using actual sales.

The access to actual annuity sales represents a significant improvement over other studies, because the computed MWRs are more consistent with the value actually provided to customers. Another advantage of the study is the much larger size of the sample and the wider range of data points generated. This allows more robust estimates of the averages of different categories, the econometric analysis of some of the main determinants of MWRs, and a more robust analysis of dispersion of annuity prices and transparency of the annuities market.

At the same time, it is important to recognize the possible problems of comparability with other studies. The use of actual annuity sales may lead to higher MWRs than those computed with quotations, even in cases where there are no real differences. This is because customers receive a number of quotes and typically exercise preference for one of the better quotes. Therefore, data based on actual annuity sales will typically capture the better quotes, while data based on quotations will typically reflect the average of several quotes. As a result, MWRs produced with actual sales will tend to be higher. ${ }^{8}$ The much larger sample used in this study may also be a source of differences. If the quotations collected in other studies are not representative of the universe of annuity sales, the results and comparisons may be biased.

\footnotetext{
${ }^{7}$ The authors are grateful to the assistance provided by Messrs. Klaus Schmidt-Hebel and Jorge Perez, of the Central Bank of Chile. The Central Bank adjustments result in higher yields than those generated by the direct application of the RiskAmerica software.

${ }^{8}$ This problem is recognized by Cannon and Tonks (2004).
} 
The dataset used in this study comprises 937 annuities issued in March of 1999, 1,517 annuities issued in March of 2002, 1,193 annuities issued in March of 2003, 1,490 annuities issued in March of 2004, and 1,391 annuities issued in March of 2005. These 5,137 annuities only include normal old age retirement and early retirement annuities, and exclude disability and survivorship annuities. Table 3 provides summary statistics for the whole dataset, while Table 4 provides information for separate subgroups.

As shown in Table 3, until 2004 the average age of retiring males and females was about 58 and 56, respectively, well below the normal retirement age of 65 and 60, and reflecting the large numbers of early retirees. The average age of retirement increased significantly in 2005, reflecting the introduction of stricter rules for early retirement. The share of deferred annuities (i.e., TWs) increased from 20 to 30 percent of the total, but the period of deferment remained short - roughly 80 percent of deferred annuities were only deferred for a year, and only 3 percent or less were deferred for 3 years or more. These patterns of selection reflect at least to some extent the influence of annuity brokers since commissions are determined by the size of the annuity premium, brokers do not have incentives to recommend TWs paired with long periods of deferment.

While only 30 percent of annuities issued were deferred, close to 80 percent had payments guaranteed for a certain period of time independent of survivorship. The length of the guaranteed period is also relatively high - roughly 60 percent of all guaranteed annuities had a 10-year guarantee, and 90 percent were guaranteed for 10 or 15 years. The choice of guaranteed versus non-guaranteed annuities is not prescribed or influenced by broker activity, as the commission does not depend on whether the annuity is guaranteed or not. The preference for guaranteed payments probably reflects a decision to smooth retirement income within the family unit, as well as a bequest motive.

Table 3: Summary Statistics of the Dataset

\begin{tabular}{l|ccccc}
\hline & $\mathbf{1 9 9 9}$ & $\mathbf{2 0 0 2}$ & $\mathbf{2 0 0 3}$ & $\mathbf{2 0 0 4}$ & $\mathbf{2 0 0 5}$ \\
\hline All Cases & & & & & \\
Number & 937 & 1,517 & 1,193 & 1,490 & 1,391 \\
Average Age of Males & 57.83 & 56.98 & 57.77 & 57.70 & 59.46 \\
Average Age of Females & 55.76 & 54.85 & 55.55 & 56.02 & 58.46 \\
Average Purchase Price (UF) & $1,971.66$ & $1,859.65$ & $2,116.94$ & $2,098.79$ & $2,454.9$ \\
Number of cases with & 199 & 331 & 307 & 409 & 419 \\
deferment & $(21.2 \%)$ & $(21.8 \%)$ & $(25.7 \%)$ & $(27.5 \%)$ & $(30.1 \%)$ \\
Of which: & & & & & \\
- 12 months & 164 & 275 & 238 & 322 & 315 \\
- 24 months & 32 & 54 & 60 & 75 & 91 \\
- 36 months & 2 & 2 & 8 & 10 & 9 \\
- 48 months & 1 & 0 & 1 & 2 & 3 \\
Number of cases with & 708 & 1,191 & 948 & 1,153 & 1,093 \\
a guaranteed term & $(75.6 \%)$ & $(78.5 \%)$ & $(79.5 \%)$ & $(77.4 \%)$ & $(78.6 \%)$ \\
Of which: & & & & & \\
- 5 years & 11 & 19 & 17 & 18 & 23 \\
- 10 years & 422 & 701 & 511 & 636 & 559 \\
- 15 years & 244 & 387 & 335 & 380 & 353 \\
- 20 years & 18 & 64 & 63 & 93 & 124 \\
- other & 13 & 20 & 22 & 26 & 34 \\
\hline
\end{tabular}

Source: SVS and Staff Analysis 
Table 4 provides more detailed information, showing that joint life annuities accounted for approximately 70 percent of all annuities issued in the sample months. Single female and single male annuities accounted for around 20 and 10 percent of the total, respectively. The large share of joint annuities is an important feature of the Chilean pension system, as it ensures retirement income for surviving spouses and helps prevent a large number of old people (mostly women) falling into poverty, or having to access the minimum pension guarantee. The large share of joint annuities is to a large extent due to product regulation - retiring married males can only buy joint annuities. However, the large share of guaranteed joint annuities reveals an element of voluntary transfers within the family unit - as mentioned before, the main beneficiary accepts voluntarily a discounted annuity in exchange for a higher annuity for his spouse during the guaranteed period (higher than the standard 60 percent reversionary payment), in the event of his death during this period.

The high share of guaranteed annuities in the case of single male and single female annuities reflects primarily a bequest motive, with the main beneficiary accepting a discount in exchange for the guarantee of some value to his/her heirs in the event of his/her death. The increase in the share of TWs and deferred annuities reveals the consumers' preference for larger payments in the early phases of retirement and may reflect the use of TWs and deferments as a substitute for the loss of access to lump-sums.

\section{Analysis of Money's Worth Ratios}

As mentioned before, most empirical studies present estimates of MWRs computed with two mortality tables (the annuitant and the population tables) and with two discount rates (the government and the corporate bond rate). Moreover, these four estimates are presented separately for single male, single female and joint annuities. Some studies present MWRs of guaranteed annuities, whenever such information is available. In the very few countries that offer indexed annuities, such estimates are presented as well.

The lack of a reliable and updated population table for Chile reduces the value of the traditional exercise of comparing MWRs with population and annuitant tables to estimate the impact of adverse selection. Moreover, even if a reliable and current mortality table for the population was available, the exercise would still have limited value, as only 60 percent of the Chilean population is on average covered by the pension system, a much lower coverage ratio than the ratios of OECD countries for which MWRs have been computed. The uncovered segment of the population is the segment with the lowest incomes and probably the lowest life expectancies. Therefore, an exercise of this type would produce exaggerated measures of adverse selection in the Chilean case.

On the other hand, the availability of a larger dataset of individual annuities in the Chilean case allows a much more detailed examination of MWRs across different types of annuitants. This section analyzes in detail the MWRs computed with the risk-free rate and the cohortized RV-04 table, considered the most relevant in the Chilean case. The analysis includes the examination of the MWRs for the main classes of annuities, an econometric investigation of the individual MWRs against individual annuitant 
characteristics, and an analysis of dispersion of MWRs. The next section compares MWRs for annuitants in Chile with those estimated for annuitants in other countries, computed both with the risk-free rate and a higher discount rate.

Table 4: Summary Statistics of Dataset by Subgroups

\begin{tabular}{|c|c|c|c|c|c|}
\hline & 1999 & 2002 & 2003 & 2004 & 2005 \\
\hline \multicolumn{6}{|l|}{ Sinqle Life-Males } \\
\hline Number & 82 & 139 & 114 & 144 & 108 \\
\hline Average Age of Males & 59.22 & 57.49 & 57.81 & 58.13 & 59.74 \\
\hline Average Purchase Price (UF) & $1,475.85$ & 1678.00 & $1,544.60$ & $1,631.88$ & 1973.34 \\
\hline Number of cases with deferment & $\begin{array}{c}7 \\
(8.5 \%)\end{array}$ & $\begin{array}{c}22 \\
(15.8 \%)\end{array}$ & $\begin{array}{c}14 \\
(12.3 \%)\end{array}$ & $\begin{array}{c}22 \\
(15.3 \%)\end{array}$ & $\begin{array}{c}25 \\
(23.1 \%)\end{array}$ \\
\hline O/w: - 12 months & 6 & 16 & 12 & 17 & 22 \\
\hline-24 months & 1 & 6 & 1 & 5 & 2 \\
\hline - 36 months and longer & 0 & 0 & 1 & 0 & 1 \\
\hline Number of cases with a guaranteed term & $\begin{array}{c}52 \\
(63.4 \%)\end{array}$ & $\begin{array}{c}102 \\
(73.4 \%)\end{array}$ & $\begin{array}{c}85 \\
(74.6 \%)\end{array}$ & $\begin{array}{c}101 \\
(70.1 \%)\end{array}$ & $\begin{array}{c}75 \\
(69.4 \%)\end{array}$ \\
\hline O/w: - 5 years & 0 & 5 & 4 & 7 & 7 \\
\hline - 10 years & 39 & 68 & 56 & 52 & 41 \\
\hline-15 years & 10 & 19 & 18 & 27 & 17 \\
\hline - 20 years and longer & 1 & 10 & 7 & 15 & 8 \\
\hline \multicolumn{6}{|l|}{ Single Life - Females } \\
\hline Number & 185 & 309 & 256 & 373 & 520 \\
\hline Average Age of Females & 57.89 & 56.46 & 57.51 & 58.66 & 60.99 \\
\hline Average Purchase Price (UF) & $1,779.28$ & $1,619.47$ & $1,984.87$ & $2,007.26$ & $2,187.79$ \\
\hline Number of cases with deferment & $\begin{array}{c}44 \\
(23.8 \%)\end{array}$ & $\begin{array}{c}69 \\
(22.3 \%)\end{array}$ & $\begin{array}{c}71 \\
(27.7 \%)\end{array}$ & $\begin{array}{c}113 \\
(30.3 \%)\end{array}$ & $\begin{array}{c}175 \\
(33.7 \%)\end{array}$ \\
\hline O/w: - 12 months & 37 & 57 & 56 & 81 & 132 \\
\hline - 24 months & 7 & 12 & 12 & 27 & 38 \\
\hline - 36 months and longer & 0 & 0 & 3 & 5 & 5 \\
\hline Number of cases with a guaranteed term & $\begin{array}{c}151 \\
(81.6 \%)\end{array}$ & $\begin{array}{c}250 \\
(80.9 \%)\end{array}$ & $\begin{array}{c}208 \\
(81.3 \%)\end{array}$ & $\begin{array}{c}310 \\
(83.1 \%)\end{array}$ & $\begin{array}{c}416 \\
(80.0 \%)\end{array}$ \\
\hline O/w: - 5 years & 1 & 3 & 2 & 5 & 8 \\
\hline-10 years & 89 & 149 & 120 & 175 & 217 \\
\hline-15 years & 53 & 82 & 70 & 104 & 138 \\
\hline - 20 years and longer & 5 & 16 & 16 & 26 & 41 \\
\hline \multicolumn{6}{|l|}{ Joint Life } \\
\hline Number & 670 & 1,069 & 823 & 973 & 763 \\
\hline Average Age of Males & 57.66 & 56.92 & 57.77 & 57.64 & 59.42 \\
\hline Average Age of Females & 55.17 & 54.39 & 54.94 & 55.01 & 56.73 \\
\hline $\begin{array}{l}\text { Average Age difference (male age less } \\
\text { female age) in years }\end{array}$ & 2.49 & 2.53 & 2.83 & 2.62 & 2.69 \\
\hline Average Purchase Price (UF) & $2,085.47$ & 1952.69 & 2237.30 & 2202.07 & 2705.19 \\
\hline Number of cases with deferment & $\begin{array}{c}148 \\
(22.1 \%)\end{array}$ & $\begin{array}{c}240 \\
(22.5 \%)\end{array}$ & $\begin{array}{c}222 \\
(27.0 \%)\end{array}$ & $\begin{array}{c}274 \\
(28.2 \%)\end{array}$ & $\begin{array}{c}219 \\
(28.7 \%)\end{array}$ \\
\hline O/w: - 12 months & 121 & 202 & 170 & 224 & 161 \\
\hline - 24 months & 24 & 36 & 47 & 43 & 51 \\
\hline - 36 months and longer & 3 & 2 & 5 & 7 & 7 \\
\hline Number of cases with a guaranteed term & $\begin{array}{c}504 \\
(75.2 \%)\end{array}$ & $\begin{array}{c}839 \\
(78.4 \%)\end{array}$ & $\begin{array}{c}655 \\
(79.6 \%)\end{array}$ & $\begin{array}{c}742 \\
(76.3 \%)\end{array}$ & $\begin{array}{c}602 \\
(78.9 \%)\end{array}$ \\
\hline O/w: - 5 years & 9 & 11 & 11 & 6 & 8 \\
\hline - 10 years & 293 & 484 & 335 & 409 & 301 \\
\hline - 15 years & 181 & 286 & 247 & 249 & 198 \\
\hline - 20 years and longer & 14 & 58 & 62 & 78 & 75 \\
\hline
\end{tabular}

Source: SVS and Staff Analysis 


\subsection{An Overview of the Results}

Table 5 presents estimates of MWRs for March of 1999, 2002, 2003, 2004 and 2005, using the cohortized version of the most updated mortality table for the annuitant population (the RV-04), and the risk-free yield curve. ${ }^{9}$ The table shows the overall averages for each of the five years, the maximum and the minimum, and the averages for well defined categories, including type, age, gender, size of the premium, and the presence of guaranteed and deferred periods. It must be emphasized that these are MWRs computed for indexed annuities.

Table 5: Money's Worth Ratios in March of 1999, 2002, 2003, 2004 and 2005 Computed with the Risk Free Rate and an Update Cohort Annuitant Table

\begin{tabular}{lccccc}
\hline & March & March & March & March & March \\
& $\mathbf{1 9 9 9}$ & $\mathbf{2 0 0 2}$ & $\mathbf{2 0 0 3}$ & $\mathbf{2 0 0 4}$ & $\mathbf{2 0 0 5}$ \\
\hline All cases & 0.978 & 1.079 & 1.036 & 1.064 & 1.062 \\
- maximum & 1.148 & 1.222 & 1.181 & 1.276 & 1.223 \\
- minimum & 0.755 & 0.872 & 0.872 & 0.876 & 0.706 \\
Male Single Life & 0.987 & 1.086 & 1.044 & 1.061 & 1.054 \\
Female Single Life & 1.009 & 1.111 & 1.063 & 1.097 & 1.086 \\
Joint Life & 0.968 & 1.070 & 1.026 & 1.052 & 1.046 \\
Male Single Life age 55 & 0.981 & 1.075 & 1.034 & 1.049 & 1.042 \\
Male Single Life age 65 & 0.996 & 1.117 & 1.069 & 1.086 & 1.067 \\
Female Single Life age 55 & 0.994 & 1.101 & 1.049 & 1.076 & 1.064 \\
Female Single Life age 60 & 1.021 & 1.131 & 1.077 & 1.105 & 1.083 \\
Joint Life - Male 65 and Female 60 & 0.998 & 1.083 & 1.050 & 1.078 & 1.069 \\
Purchase Price up to UF 1,000 & 0.980 & 1.078 & 1.045 & 1.068 & 1.067 \\
Purchase Price above UF 3,000 & 0.997 & 1.099 & 1.047 & 1.075 & 1.071 \\
Without guaranteed term & 0.990 & 1.092 & 1.045 & 1.071 & 1.073 \\
With guaranteed term & 0.974 & 1.076 & 1.033 & 1.062 & 1.059 \\
Without deferment & 0.979 & 1.079 & 1.035 & 1.063 & 1.061 \\
With deferment & 0.974 & 1.080 & 1.036 & 1.067 & 1.064 \\
\hline
\end{tabular}

The first thing to note is that the average MWR in 1999 is slightly lower than one, a value that is usually taken to indicate a fairly priced annuity. In 2002 and the following years average MWRs are all higher than one, and also higher than MWRs estimated for other countries. As shown in more detail in the next section, MWRs of nominal annuities estimated with similar assumptions usually range from 0.9 to levels slightly above 1 and are much lower in the case of indexed annuities.

Second, there is a significant variation in individual MWRs, as indicated by the wide difference between maximum and minimum values. Maximum values range roughly from 1.15 to 1.25 and minimum values range from 0.75 to 0.85 . These variations reflect to a good extent price differentiation by providers based on the individual characteristics of annuitants, but they may also reflect inefficiencies, as discussed below.

\footnotetext{
${ }^{9}$ As mentioned before, the month of March was selected simply to allow comparisons with previous estimates made by other researchers. These comparisons are provided below.
} 
Third, the MWRs of joint annuities are lower than those of single annuities, and the MWRs of single male annuities are lower than those of females. One possible explanation for the lower MWRs of joint annuities (the bulk of the annuities market) is their longer expected duration and consequent greater mortality and reinvestment risk relative to single life annuities. Greater risk would justify an increase in premiums for a given value of benefits, and therefore a lower MWR. However, the same argument would apply to single female annuities relative to males, and yet the MWRs of females turn out to be higher. A possible further explanation is the larger average premium of single female annuitants relative to single male annuitants (Table 4) but it is also recognized that the number of single life male cases is small. The relationship between MWRs and premiums will be discussed further below.

Fourth, MWRs of older annuitants are systematically higher than those of younger annuitants, regardless of gender. This positive relationship between MWRs and age can be explained by the greater mortality and reinvestment uncertainty associated with annuities issued to younger ages, and the inclusion of a risk premium (a smaller annuity relative to the premium) by the provider. This result contrasts with those produced by Mitchell et al (2001) and Brown et al (2001) for the US and the UK, respectively, but is consistent with those reported by James, Iglesias and Martinez (2005) for Chile.

Fifth, there is a positive relationship between MWRs and the size of the premium. This result could be due to the lower unit costs and higher profit margins associated with larger premiums - insurance companies may pay better rates for larger annuity premiums just like banks pay higher interest rates for larger deposits. The positive association could also reflect the more sophisticated market search by educated consumers with higher incomes and larger premiums. These two effects probably offset the longevity effect, which would produce a negative relationship - retirees with higher incomes and larger premiums tend to have higher life expectancies and expose providers to greater risks due to the longer expected duration of their annuities.

Sixth, MWRs of guaranteed annuities are smaller than those of non-guaranteed annuities. The interpretation of this result is confused by the fact that the guarantee can alter the duration, and therefore the reinvestment risk, positively or negatively depending on the length of the guarantee relative to the life expectancy of the annuitant. Long periods of guarantee tend to increase duration, especially at older ages. Finkelstein and Poterba (1999) obtain exactly opposite results for the UK, and interpret these results as evidence of adverse selection in the UK annuity market. According to the argument, individuals who expect to be longer-lived would self-select into non-guaranteed annuities, while individuals who are concerned about the potential for early death would self-select into guaranteed annuities (to leave a bequest or guarantee larger payments for the surviving spouse). If this interpretation is correct, the results in Table 5 would suggest the absence of adverse selection in Chile.

Finally, deferment periods seem to make little difference in the value offered to the customer. However, this result may be simply due to the preponderance of very short deferments in the Chilean market. 


\subsection{Econometric Analysis of MWRs}

Most empirical studies examine the differences of MWRs across different classes of annuities without testing whether these differences are significant. The large dataset of individual annuities in Chile enables a more formal examination of the main determinants of MWRs, and the testing of whether the relationships identified above are significant. For this purpose we specify the MWR as a function of individual annuitant characteristics, as in equation (3):

$$
\mathrm{MWR}_{\mathrm{i}, \mathrm{t}}=\mathrm{f} \text { (gender }_{\mathrm{i}, \mathrm{t}} \text { age }_{\mathrm{i}, \mathrm{t}} \text {, } \text { premium }_{\mathrm{i}, \mathrm{t}}, \text { guarantee }_{\mathrm{i}, \mathrm{t}}, \text { deferment }_{\mathrm{i}, \mathrm{t}} \text { ) }
$$

Where $\mathrm{MWR}_{\mathrm{i}}$ is the money's worth ratio of the annuity bought by individual $\mathrm{i}$ at time $\mathrm{t}$, regressed against the gender and age of the individual annuitant, the size of the annuity premium expressed in logs, and the guaranteed and deferment periods. Since the bulk of the market is constituted by joint annuities, the equation was estimated using this type of annuity as the base variable and dummies included for single male and single female annuities. Likewise, 1999 was considered as the base year and dummies were included for 2002, 2003, 2004, and 2005. Table 6 shows the results obtained through least squares with robust standard errors. This specification was selected after conducting a number of specification tests, including the White test for heteroskedasticity of the residuals.

Table 6: Main Determinants of MWRs

Dependent Variable: 100*MWR; Least Squares with Robust Standard Errors

Pooled Data for 1999, 2002, 2003, 2004, and 2005; Observations: 6526

\begin{tabular}{ccccc}
\hline \hline Variable & Coefficient & Std. Error & t-Statistic & Prob. \\
\hline \hline C & 62.39024 & 0.722912 & 86.30404 & 0.0000 \\
AGE & 0.410145 & 0.008974 & 45.70317 & 0.0000 \\
LOG(PREMIUM) & 1.618070 & 0.073313 & 22.07059 & 0.0000 \\
GUARANTEE & -0.134448 & 0.008383 & -16.03824 & 0.0000 \\
DEFERMENT & 0.016582 & 0.007399 & 2.241063 & 0.0251 \\
Male & 1.345882 & 0.206458 & 6.518928 & 0.0000 \\
Female & 4.023704 & 0.089566 & 44.92436 & 0.0000 \\
2002 & 10.66352 & 0.149209 & 71.46677 & 0.0000 \\
2003 & 5.699579 & 0.152080 & 37.47739 & 0.0000 \\
2004 & 8.253581 & 0.150549 & 54.82318 & 0.0000 \\
2005 & 6.507061 & 0.156551 & 41.56508 & 0.0000 \\
\hline R-squared & 0.639507 & \multicolumn{2}{c}{ Mean dependent var } & 104.9609 \\
Adjusted R-squared & 0.638954 & S.D. dependent var & 5.600486 \\
S.E. of regression & 3.365172 & Akaike info criterion & 5.266519 \\
Sum squared resid & 73778.36 & Schwarz criterion & 5.277954 \\
Log likelihood & -17173.65 & F-statistic & 1155.747 \\
Durbin-Watson stat & 1.754037 & \multicolumn{2}{c}{ Prob(F-statistic) } & 0.000000 \\
\hline \hline
\end{tabular}

Source: Authors' estimations on SVS data. 
Equation (3) explains about 65 percent of the variations of MWRs within the pooled sample, and the results confirm the signs and significance of all the relationships examined above. MWRs are positively and significantly related to age, in contrast with the results of other researchers for the UK and the US, indicating that the risk associated with younger ages and longer durations is an important factor in annuity pricing in Chile. MWRs are also positively and significantly related to the size of the premium, indicating that the cost and market search effects offset the longevity effect. MWRs are negatively associated with longer periods of guarantee, again providing support to the hypothesis that longer durations imply greater risk for the provider and have a negative impact on MWRs.

As mentioned before, the negative coefficient for the guarantee variable could reveal the absence of adverse selection effects in the Chilean annuities market. Alternatively, it could reflect the net result of two different effects. Maybe higher income members with longer life expectancies self-select into non-guaranteed annuities and members with shorter life expectancies self-select into guaranteed ones, but the longevity risk is outweighed by the reinvestment risk. James, Iglesias and Martinez (2005) examine actual/expected death ratios of guaranteed and non-guaranteed annuitants and show lower ratios for members with non-guaranteed annuities, indicating that individuals with longer life expectancies self-select into these annuities. Although their results are overestimated by the use of outdated mortality tables (the RV-85 and the RV-98), this is a more direct test of self-selection and provides evidence of some adverse selection in the Chilean annuities market. Therefore, the coefficient of the guarantee variable may not provide a robust test for adverse selection.

The positive and significant coefficient for the deferment variable is perhaps surprising, although this result should not be emphasized, given the very short length of deferments in Chile. Moreover, this was the only variable that proved non-significant at the 5 percent level when the equation was estimated separately for each year (these results are shown below). Finally, the signs of the male an female dummy variables are consistent with the relationships among the average MWRs for joint, single male and single female annuities, although the sign of the female dummy coefficient does not have an obvious explanation.

Overall, the major conclusions to be drawn from this analysis is that, in Chile, there is evidence that annuities with longer expected durations get lower MWRs than annuities with shorter durations, and that larger premiums get better value on average than smaller ones. This is consistent with the view that insurers are concerned with the higher reinvestment and mortality risks presented by long durations and, in the case of size, the effect of fixed expense loadings is more significant in the Chilean market than attempts to differentiate mortality between annuitants of different income levels. An additional factor, the relevance of niche marketing and more sophisticated and price sensitive customers at higher premiums, may also be an explanation.

Additional insights on individual annuity pricing can also be gained by examining the pairs of correlation coefficients across these variables. As shown in Table 7, the 
relationship between premium size and age is positive but not statistically significant. A positive correlation would be expected, as older retirees would have more time to accumulate a higher balance. However, this positive association is weakened by the strong association between annuitization and early retirement in Chile, caused in good part by early retirement rules that facilitate retirement by higher income workers with larger premiums, and also the influence of brokers, that induce early retirement.

The relationship between deferment and age is negative, suggesting that older retirees are less likely to opt for TWs than younger retirees. Given the relatively small volume of such cases, however, and the rational desire for flexibility for younger retirees, this is understandable. The negative and significant relationship between guarantee periods and age suggests a strong reaction by early retirees to the risk of reduction on reversion after the first death, or a stronger bequest motive among early retirees. The positive association between premiums and the length of guarantee periods indicates that higher income annuitants are more willing and capable of buying the guarantee, i.e., accepting a discount in the early payments relative to the premium in exchange for larger payments for the surviving spouse.

Tables 8 through 12 present the results obtained for individual years, showing that equation (3) explains 40-50 percent of the variations in MWRs in each year. The coefficients have the same signs as those obtained in the pooled sample and are significant, except for the deferment variable, which proved non-significant at the 5 percent level in all individual years.

Table 7: Variable Correlation Matrix

\begin{tabular}{l|ccccc}
\hline & MWR & Age & Premium & Deferment & Guarantee \\
\hline MWR & 1 & & & & \\
Age & $0.4626^{*}$ & 1 & & & \\
Premium & $0.1744^{*}$ & 0.0297 & 1 & & \\
Deferment Period & 0.0277 & $-0.0490^{*}$ & $0.0729 *$ & 1 & \\
Guaranteed Period & $-0.1713^{*}$ & $-0.1455^{*}$ & $0.2077^{*}$ & $0.0962 *$ & 1 \\
\hline
\end{tabular}


Table 8: Main Determinants of MWRs

Dependent Variable: 100*MWR; Least Squares with Robust Standard Errors

YEAR=1999; Observations: 937

\begin{tabular}{ccccc}
\hline \hline Variable & Coefficient & Std. Error & t-Statistic & Prob. \\
\hline \hline C & 60.86516 & 2.100710 & 28.97362 & 0.0000 \\
AGE & 0.406372 & 0.023248 & 17.47959 & 0.0000 \\
LOG(PREMIUM) & 1.854153 & 0.227955 & 8.133850 & 0.0000 \\
GUARANTEE & -0.136101 & 0.023538 & -5.782169 & 0.0000 \\
DEFERMENT & -0.006032 & 0.022320 & -0.270278 & 0.7870 \\
Male & 1.639658 & 0.522999 & 3.135107 & 0.0018 \\
Female & 4.316622 & 0.286877 & 15.04697 & 0.0000 \\
\hline \hline R-squared & 0.407434 & Mean dependent var & 97.81531 \\
Adjusted R-squared & 0.403611 & S.D. dependent var & 4.899386 \\
S.E. of regression & 3.783611 & Akaike info criterion & 5.506677 \\
Sum squared resid & 13313.61 & Schwarz criterion & 5.542855 \\
Log likelihood & -2572.878 & F-statistic & 106.5742 \\
Durbin-Watson stat & 1.903532 & Prob(F-statistic) & 0.000000 \\
\hline \hline
\end{tabular}

Table 9: Main Determinants of MWRs

Dependent Variable: 100*MWR; Least Squares with Robust Standard Errors YEAR=2002; Observations: 1,517

\begin{tabular}{ccccc}
\hline \hline Variable & Coefficient & Std. Error & t-Statistic & Prob. \\
\hline \hline C & 65.91515 & 1.296474 & 50.84185 & 0.0000 \\
AGE & 0.499496 & 0.016820 & 29.69642 & 0.0000 \\
LOG(PREMIUM) & 1.862513 & 0.144434 & 12.89526 & 0.0000 \\
GUARANTEE & -0.118013 & 0.016261 & -7.257291 & 0.0000 \\
DEFERMENT & 0.025761 & 0.015423 & 1.670247 & 0.0951 \\
Male & 1.352054 & 0.394186 & 3.429992 & 0.0006 \\
Female & 4.419103 & 0.179380 & 24.63540 & 0.0000 \\
\hline \hline R-squared & 0.536716 & Mean dependent var & 107.9591 \\
Adjusted R-squared & 0.534875 & S.D. dependent var & 4.709875 \\
S.E. of regression & 3.212139 & Akaike info criterion & 5.176355 \\
Sum squared resid & 15579.93 & Schwarz criterion & 5.200924 \\
Log likelihood & -3919.265 & F-statistic & 291.5563 \\
Durbin-Watson stat & 1.614660 & Prob(F-statistic) & 0.000000 \\
\hline \hline
\end{tabular}


Table 10: Main Determinants of MWRs

Dependent Variable: 100*MWR; Least Squares with Robust Standard Errors YEAR=2003; Observations: 1,191

\begin{tabular}{ccccc}
\hline \hline Variable & Coefficient & Std. Error & t-Statistic & Prob. \\
\hline \hline C & 70.19722 & 1.505577 & 46.62479 & 0.0000 \\
AGE & 0.406500 & 0.018254 & 22.26915 & 0.0000 \\
LOG(PREMIUM) & 1.356398 & 0.142582 & 9.513102 & 0.0000 \\
GUARANTEE & -0.133558 & 0.016452 & -8.117811 & 0.0000 \\
DEFERMENT & 0.020258 & 0.013499 & 1.500708 & 0.1337 \\
Male & 2.042872 & 0.376537 & 5.425418 & 0.0000 \\
Female & 3.864239 & 0.220587 & 17.51798 & 0.0000 \\
\hline \hline R-squared & 0.478898 & Mean dependent var & 103.5660 \\
Adjusted R-squared & 0.476257 & S.D. dependent var & 4.219287 \\
S.E. of regression & 3.053501 & Akaike info criterion & 5.076315 \\
Sum squared resid & 11039.46 & Schwarz criterion & 5.106187 \\
Log likelihood & -3015.945 & F-statistic & 181.3513 \\
Durbin-Watson stat & 1.269357 & Prob(F-statistic) & 0.000000 \\
\hline \hline
\end{tabular}

Table 11: Main Determinants of MWRs

Dependent Variable: 100*MWR; Least Squares with Robust Standard Errors YEAR=2004; Observations: 1,490

\begin{tabular}{ccccc}
\hline \hline Variable & Coefficient & Std. Error & t-Statistic & Prob. \\
\hline \hline C & 74.47563 & 1.466312 & 50.79111 & 0.0000 \\
AGE & 0.380927 & 0.018095 & 21.05134 & 0.0000 \\
LOG(PREMIUM) & 1.335759 & 0.146455 & 9.120596 & 0.0000 \\
GUARANTEE & -0.141260 & 0.017002 & -8.308617 & 0.0000 \\
DEFERMENT & 0.018659 & 0.014863 & 1.255400 & 0.2095 \\
Male & 0.896550 & 0.455371 & 1.968831 & 0.0492 \\
Female & 4.289322 & 0.172651 & 24.84389 & 0.0000 \\
\hline \hline R-squared & 0.465397 & Mean dependent var & 106.3872 \\
Adjusted R-squared & 0.463234 & S.D. dependent var & 4.509411 \\
S.E. of regression & 3.303790 & Akaike info criterion & 5.232704 \\
Sum squared resid & 16186.98 & Schwarz criterion & 5.257634 \\
Log likelihood & -3891.365 & F-statistic & 215.1699 \\
Durbin-Watson stat & 1.798048 & Prob(F-statistic) & 0.000000 \\
\hline \hline
\end{tabular}


Table 12: Main Determinants of MWRs

Dependent Variable: 100*MWR; Least Squares with Robust Standard Errors YEAR=2005; Observations: 1,391

\begin{tabular}{ccccc}
\hline \hline Variable & Coefficient & Std. Error & t-Statistic & Prob. \\
\hline \hline C & 72.51743 & 1.879981 & 38.57349 & 0.0000 \\
AGE & 0.347256 & 0.024670 & 14.07629 & 0.0000 \\
LOG(PREMIUM) & 1.667719 & 0.165144 & 10.09859 & 0.0000 \\
GUARANTEE & -0.137314 & 0.019536 & -7.028687 & 0.0000 \\
DEFERMENT & 0.017231 & 0.016807 & 1.025200 & 0.3054 \\
Male & 0.847786 & 0.554230 & 1.529663 & 0.1263 \\
Female & 3.600156 & 0.184605 & 19.50199 & 0.0000 \\
\hline \hline R-squared & 0.407568 & Mean dependent var & 106.1712 \\
Adjusted R-squared & 0.405000 & S.D. dependent var & 4.506864 \\
S.E. of regression & 3.476427 & Akaike info criterion & 5.334907 \\
Sum squared resid & 16726.39 & Schwarz criterion & 5.361265 \\
Log likelihood & -3703.427 & F-statistic & 158.6889 \\
Durbin-Watson stat & 2.027204 & Prob(F-statistic) & 0.000000 \\
\hline \hline
\end{tabular}

\subsection{Analysis of Dispersion of MWRs}

An efficient and transparent annuities market should produce similar prices (or MWRs) for customers with similar characteristics. The results above indicate that annuity pricing is influenced by the characteristics of the annuitant such as age and gender, but the regression does not explain a relatively large share of the variations of MWRs across individual annuitants and over time. The unexplained variations in MWRs could be simply due to the absence of key explanatory variables, such as the level of education of individual annuitants and their geographical location, as well as variables capturing provider characteristics. These limitations could not be overcome, as the dataset on individual annuities used to compute MWRs does not provide information on providers or further information on the characteristics of annuitants, beyond those explored above.

The dispersion of MWRs could also be due to institutional and regulatory inefficiencies, such as the lack of a transparent pricing system and the excessive influence of brokers. The influence of these factors may be examined, because during this period there were substantial efforts to improve market transparency. As mentioned before, a major development in the annuities market was the passage of a new Pensions Law in 2004 that, among other factors, introduced a cap on broker's commissions and an electronic quotation system that allows easy and transparent comparisons of annuity and PW prices. The draft of the Pensions Law was first submitted to Congress in 2000, and it is possible that the market started changing behavior in anticipation of the Law's approval. Such 
change in behavior was observed in the sharp reduction in broker's commissions, from 6 percent of the premium in 1999 to 2.5 percent before approval of the Law in $2004 .^{10}$ If annuity rates became the main element of price competition, as opposed to other sales tactics that included cash rebates to annuitants, it would be reasonable to expect less dispersion of MWRs.

As shown in Table 13, there was indeed a significant reduction in the dispersion of MWRs after 1999, measured by the decline in the coefficient of variation. Moreover, the reduction in dispersion was more pronounced in the bottom third of the market, i.e., for annuitants with lower premiums and incomes. The decline in the coefficient of variation was not continuous over the whole period (it was lowest in 2002 for the bottom third and lowest in 2003 for the whole market), but this is probably due to the fact that MWRs were computed only for the months of March of each year, and not for the whole year, and there were probably specific factors affecting MWRs in those particular months.

The reduction in the dispersion of MWRs after 1999 is also illustrated in Figure 3, which shows the residuals around a simple regression of MWRs against individual premiums in 1999 and 2005. It is also apparent in Figure 3 that the reduction in the dispersion of MWRs was stronger at the lower end of the market. Overall, these results are consistent with the sharp decline in broker's commissions after 1999 and probably also reflect a change in the behavior of market participants after the submission of the new Pensions Law to Congress in 2000. ${ }^{11}$ The fact that the reduction in the dispersion of MWRs was more pronounced for lower premiums is a positive development, as these MWRs are generally related to lower income annuitants without complementary sources of retirement income.

Table 13

Mean, Standard Deviation and Coefficient of Variation of MWRs in Different Years

\begin{tabular}{l|cccccccccc}
\hline & \multicolumn{3}{|c}{ March 1999 } & \multicolumn{2}{c}{ March 2002 } & \multicolumn{2}{c}{ March 2003 } & \multicolumn{2}{c}{ March 2004 } & \multicolumn{2}{c}{ March 2005 } \\
\hline & Bottom & All & Bottom & All & Bottom & All & Bottom & All & \multicolumn{3}{c}{ Bottom } & All \\
& Third & MWRs & Third & MWRs & Third & MWRs & Third & MWRs & Third & MWRs \\
\hline Mean & 0.980 & 0.980 & 1.077 & 1.080 & 1.034 & 1.036 & 1.060 & 1.064 & 1.055 & 1.062 \\
Std. Dev. & 0.049 & 0.049 & 0.041 & 0.047 & 0.043 & 0.042 & 0.042 & 0.045 & 0.041 & 0.045 \\
Coef. Var. & 4.956 & 5.009 & 3.807 & 4.363 & 4.137 & 4.074 & 3.942 & 4.239 & 3.928 & 4.245 \\
\hline
\end{tabular}

Source of raw data: SVS

Whereas the dispersion of MWRs declined after the submission of the draft Pensions Law to Congress in 2000, the effects of the actual approval and implementation of the Law in 2004 are less clear. As shown in Table 13, the coefficient of variation declined further in the bottom third of the market in March of 2005, relative to March 2004, but increased slightly for the whole market in the same period. This is somewhat surprising, as the actual implementation of the Law in mid-2004 seems to have generated further efficiency gains, as indicated by a further decline in broker’s commissions from 2.5 to 2

\footnotetext{
${ }^{10}$ See Walker (2005) and Rocha and Thorburn (2006).

${ }^{11}$ Walker (2005) and Rocha, Morales and Thorburn (2006) provide econometric analyses of the annuity rate with company data and show that there were structural shifts in the annuities market after submission of the draft Pensions Law to Congress in 2000.
} 
percent between 2004 and 2005, and evidence that annuity pricing has been based on the best quotes produced by the new quotation system. ${ }^{12}$ Therefore, it would be reasonable to expect a further reduction in the dispersion of MWRs in 2005.

Figure 3: MWRs and Premiums in 1999 and 2005
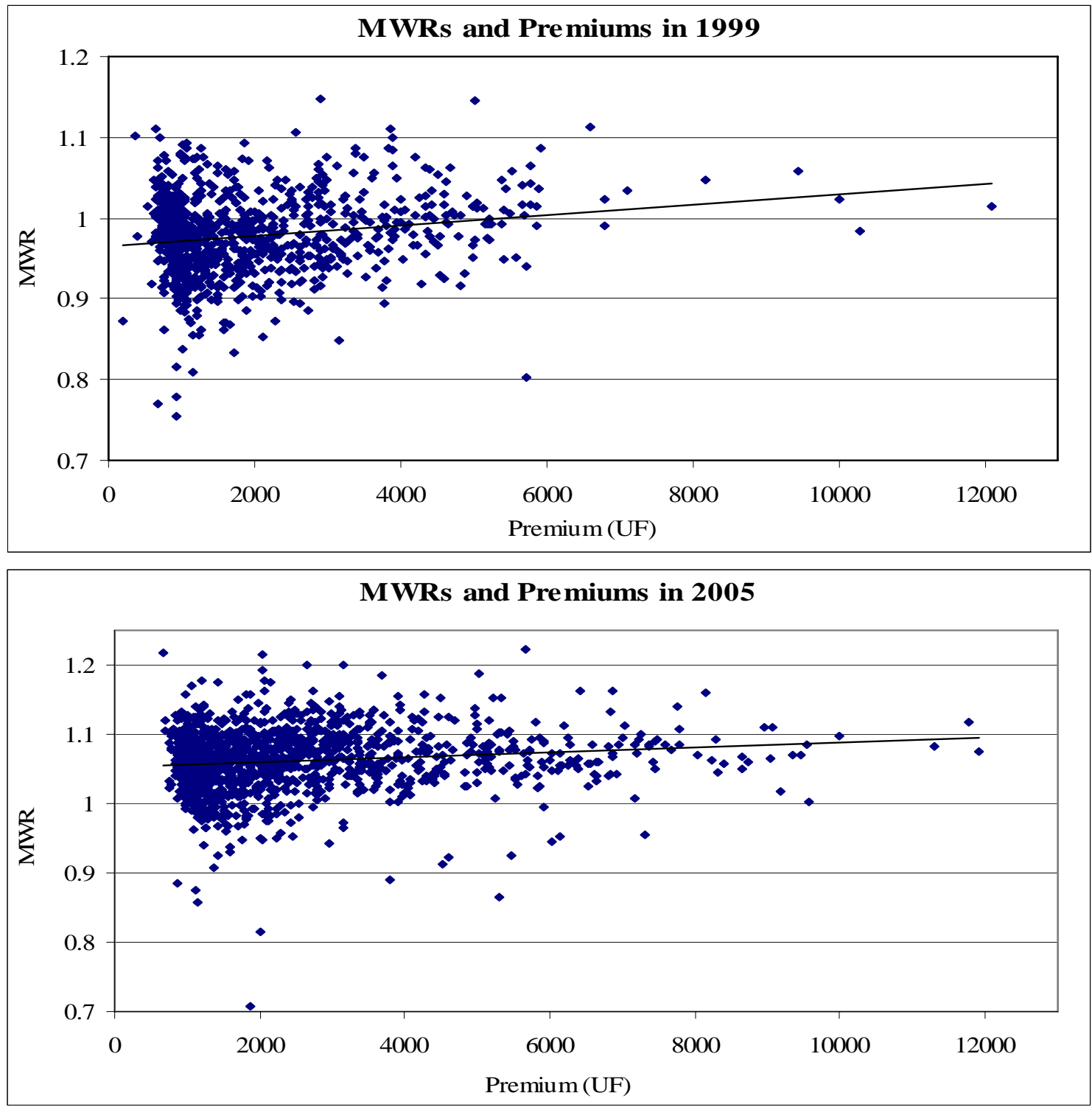

${ }^{12}$ Rocha and Thorburn (2006) provide more detailed information on the new quotation system. 
It is possible that the lack of clear evidence on the reduced dispersion of MWRs in 2005 is simply due to the limited amount of information, based only on one month. Moreover, the coefficient of variation is a limited statistic, as it does not control for changes in the individual determinants of MWRs. The White test for heterokedasticity of the residuals controls for such changes and provides some evidence, albeit limited, that dispersion declined in 2005. As shown in Table 14, the coefficients of the year dummies were all negative and significant, except for 2002, indicating that the dispersion of MWRs declined relative to 1999, the base year. Moreover, the coefficient of the 2005 dummy is higher than the 2004 dummy in absolute value, indicating that the dispersion of MWRs declined from 2004 to 2005, after controlling for changes in the determinants of MWRs, albeit by a limited amount.

Table 14: White Heteroskedasticity Test

\begin{tabular}{|c|c|c|c|c|}
\hline Obs*R-squared & 241.1479 & \multicolumn{2}{|c|}{ Probability } & 0.000000 \\
\hline \multicolumn{5}{|c|}{ 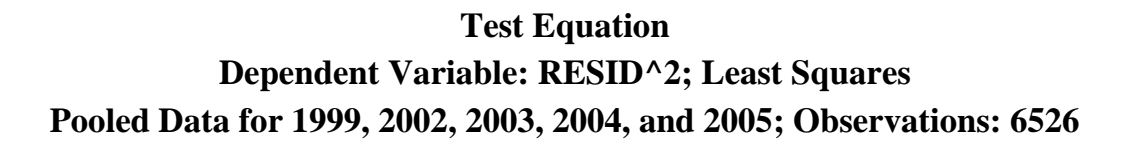 } \\
\hline Variable & Coefficient & Std. Error & t-Statistic & Prob. \\
\hline $\mathrm{C}$ & 141.1213 & 79.19219 & 1.782010 & 0.0748 \\
\hline AGE & -7.339350 & 1.377755 & -5.327035 & 0.0000 \\
\hline $\mathrm{AGE}^{\wedge} 2$ & 0.069465 & 0.011813 & 5.880583 & 0.0000 \\
\hline LOG(PREMIUM) & 17.71593 & 17.36348 & 1.020298 & 0.3076 \\
\hline$(\text { LOG }(\text { PREMIUM }))^{\wedge 2}$ & -1.177378 & 1.138494 & -1.034154 & 0.3011 \\
\hline GUARANTEE & -1.416413 & 0.228646 & -6.194797 & 0.0000 \\
\hline GUARANTEE^2 & 0.068083 & 0.012801 & 5.318755 & 0.0000 \\
\hline DEFERMENT & 0.243182 & 0.151408 & 1.606134 & 0.1083 \\
\hline DEFERMENT^2 & 0.008477 & 0.006064 & 1.398003 & 0.1622 \\
\hline Male & 11.85092 & 1.736567 & 6.824335 & 0.0000 \\
\hline Female & -2.340857 & 1.155242 & -2.026291 & 0.0428 \\
\hline 2002 & -2.758191 & 1.621989 & -1.700499 & 0.0891 \\
\hline 2003 & -4.945800 & 1.704210 & -2.902108 & 0.0037 \\
\hline 2004 & -3.741583 & 1.629701 & -2.295870 & 0.0217 \\
\hline 2005 & -3.841310 & 1.688727 & -2.274677 & 0.0230 \\
\hline R-squared & 0.036952 & \multicolumn{2}{|c|}{ Mean dependent var } & 11.30530 \\
\hline Adjusted R-squared & 0.034881 & \multicolumn{2}{|c|}{ S.D. dependent var } & 39.62918 \\
\hline S.E. of regression & 38.93189 & \multicolumn{2}{|c|}{ Akaike info criterion } & 10.16380 \\
\hline Sum squared resid & 9868670. & \multicolumn{2}{|c|}{ Schwarz criterion } & 10.17939 \\
\hline Log likelihood & -33149.48 & \multicolumn{2}{|c|}{ F-statistic } & 17.84465 \\
\hline Durbin-Watson stat & 1.947129 & \multicolumn{2}{|c|}{ Prob(F-statistic) } & 0.000000 \\
\hline
\end{tabular}


More research on MWRs is merited, because price dispersion in March of 2005 still seemed significant, and a closer inspection of the sample revealed several cases where the annuitants' age, gender, premium, and terms of the annuity purchased were similar, but MWRs were different. As mentioned before, there is separate evidence that the new quotation system has enhanced the transparency of the Chilean annuities market and has ensured that pricing is effectively based on the best quotes. The systematic computation of MWRs would provide further evidence as to whether the new quotation system is indeed eliminating market inefficiencies and reducing differences that cannot be explained by individual risk characteristics.

\section{Comparisons with Other Empirical Studies}

\subsection{Comparisons with MWR Estimates for Other Countries}

Comparing MWRs in Chile with those estimated by other researchers for other countries provides many additional insights into the performance of the Chilean annuities market. Such a comparison is done in two steps. The first involves a comparison of MWRs calculated with cohort annuitant tables and the risk-free rate. As mentioned before, this is the measure that reflects most accurately the value of the annuity to the average consumer (the annuitant), and the one most commonly used for international comparisons. The second step involves a comparison of MWRs also calculated with the cohort annuitant table, but discounted with the corporate bond rate. This measure captures more accurately the cost of the annuity to providers.

Table 15 shows a selected number of MWRs in Chile, estimated for annuities issued in March 2004. The MWRs are computed with the most updated cohort annuitant table (the cohortized RV-04) and two discount rates - the risk-free rate and the corporate bond rate. $^{13}$ Tables 16 and 17 summarize the results obtained for other countries by other researchers, using similar parameters. Most MWRs computed for other countries are nominal, i.e., they related to nominal annuities. This reflects the absence of indexed annuities in most countries - the UK is the only country in this sample that has developed indexed annuities as well. Table 16 also shows indexed MWRs for the US, based on quotations of indexed annuities by a life insurance company (ILONA). These annuities have not been sold in the US market, but are also shown for purposes of illustration.

As shown in Tables 15 and 16, the average MWRs estimated for Chile are higher than the average nominal MWRs estimated for all other countries, across all classes of annuitants. The differences between the Chilean MWRs and the MWRs of indexed annuities in the UK and the US are striking, amounting to 20 percent. The average MWRs in the US and UK decline with age, unlike in the Chilean case. The MWRs for males and females tend to be very similar in other countries, unlike in the Chilean case. MWRs of joint annuities are very similar or lower than single annuities, more similar to the pattern in Chile.

\footnotetext{
13 The year 2004 was chosen because it was the last year for which MWRs were computed both with the risk-free rate and the higher corporate bond rate.
} 
The first conclusion from a comparison of Tables 15 and 16 is that Chilean annuitants have got a better deal than annuitants in other countries, especially considering that Chilean annuities are indexed. Buyers of indexed annuities in the UK get a much lower annuity value of 86 percent of the premium, and pay a charge of about 5 percent of the premium to obtain inflation protection. The cost of inflation protection in the US is even higher, amounting to more than 20 percent of the premium. This result is in part explained by the large supply of indexed instruments in the Chilean case - unlike their British and American counterparts, Chilean providers have access not only to indexed Government bonds, but also to other higher yield instruments indexed to inflation, and that allows them to hedge inflation risk while obtaining more attractive returns.

Table 15: Money's Worth Ratios in Chile, March 2004 Computed with Cohort Annuitant Tables and Alternative Discount Rates

\begin{tabular}{l|cc}
\hline & Risk-Free Rate & Corporate Bond Rate \\
\hline All cases & 1.064 & 0.904 \\
- maximum & 1.276 & 1.146 \\
- minimum & 0.876 & 0.740 \\
Male, Age 55 & 1.049 & 0.897 \\
Male, Age 65 & 1.086 & 0.955 \\
Female, Age 55 & 1.076 & 0.905 \\
Female, Age 65 & 1.105 & 0.971 \\
Joint (65-60) & 1.078 & 0.892 \\
\hline
\end{tabular}

Table 16: Money's Worth Ratios in Selected Countries Computed with Cohort Annuitant Table and Risk-Free Rate

\begin{tabular}{l|ccccccc}
\hline & $\begin{array}{c}\text { Australia } \\
\text { (James) }\end{array}$ & $\begin{array}{c}\text { Canada } \\
\text { (James) }\end{array}$ & $\begin{array}{c}\text { Switzerl. } \\
\text { (James) }\end{array}$ & $\begin{array}{c}\text { UK }^{1} \\
\text { (Cannon) }\end{array}$ & $\begin{array}{c}\text { UK } \\
\text { (James) }\end{array}$ & $\begin{array}{c}\text { UK }^{2} \\
\text { (Brown) }\end{array}$ & $\begin{array}{c}\text { US }^{3} \\
\text { (Brown) }\end{array}$ \\
\hline Nominal Annuities & & & & & & & \\
Male, Age 55 & - & - & - & - & - & 0.921 & 0.934 \\
Male, Age 65 & 1.013 & 0.981 & 1.046 & - & 0.977 & 0.908 & 0.927 \\
Female, Age 55 & - & - & - & - & - & 0.928 & 0.937 \\
Female, Age 65 & 1.002 & 0.976 & 1.036 & - & 0.979 & 0.907 & 0.927 \\
Joint & 0.988 & 0.980 & 0.985 & 0.981 & 0.987 & - & 0.929 \\
Indexed Annuities & & - & - & - & & & \\
Male, Age 55 & - & - & - & - & - & 0.867 & - \\
Male, Age 65 & - & - & - & - & 0.887 & 0.854 & 0.822 \\
Female, Age 55 & - & - & - & - & - & 0.876 & - \\
Female, Age 65 & - & - & - & - & 0.877 & 0.857 & 0.782 \\
Joint & - & - & - & - & 0.880 & - & - \\
\hline
\end{tabular}

Notes: (1) Cannon and Tonks' estimate is the overall average; (2) For males 60 and 65 and females 60 and 65; (3) MWR for indexed annuities in the US relate to annuities offered by Irish Life of North America (ILONA), which have never been sold.

Sources: Brown et al (2002), James et al (2003), Cannon and Tonk (2004)

Workers who retire early get lower MWRs in Chile. As mentioned before, this result is explained by the higher reinvestment and mortality risks associated with annuities with longer expected duration. The opposite result in the UK and the US cannot be easily interpreted. Longer expected duration also explains the lower MWRs of joint annuities in Chile, and it is noteworthy that joint annuities have similar or lower MWRs in other 
countries as well. On the other hand, the differences between MWRs of single male and single female annuities in Chile cannot be easily explained. The larger premiums in the case of single females partly explain the higher MWRs, but even controlling for this factor, MWRs of single female annuities remain higher than those of males, as noted above. It is possible that these results are due to the small number of single male annuities.

Table 17: Average Money's Worth Ratios in Selected Countries Computed with Cohort Annuitant Table and Corporate Bond Rate

\begin{tabular}{l|ccccccc}
\hline & $\begin{array}{c}\text { Australia } \\
\text { (James) }\end{array}$ & $\begin{array}{c}\text { Canada } \\
\text { (James) }\end{array}$ & $\begin{array}{c}\text { Switzerl. } \\
\text { (James) }\end{array}$ & $\begin{array}{c}\mathrm{UK}^{1} \\
\text { (Cannon) }\end{array}$ & $\begin{array}{c}\text { UK } \\
\text { (James) }\end{array}$ & $\begin{array}{c}\mathrm{UK}^{2} \\
\text { (Brown) }\end{array}$ & $\begin{array}{c}\mathrm{US}^{3} \\
\text { (Brown) }\end{array}$ \\
\hline Nominal Annuities & & & & & & & \\
Male, Age 55 & - & - & - & - & - & - & 0.840 \\
Male, Age 65 & 0.896 & 0.879 & 0.944 & - & 0.879 & - & 0.853 \\
Female, Age 55 & - & - & - & - & - & - & 0.838 \\
Female, Age 65 & 0.865 & 0.864 & 0.916 & - & 0.860 & - & 0.847 \\
Joint & 0.846 & 0.868 & 0.875 & - & 0.873 & - & 0.841 \\
Indexed Annuities & & - & - & - & - & - & - \\
Male, Age 55 & - & - & - & - & 0.784 & - & - \\
Male, Age 65 & - & - & - & - & - & - & - \\
Female, Age 55 & - & - & - & - & - & - \\
Female, Age 65 & - & - & - & - & 0.747 & - & - \\
Joint & - & - & - & - & - & - & \\
\hline
\end{tabular}

Notes and sources: Table 13

An important question that arises in the Chilean case is whether these high MWRs are sustainable. The increase in MWRs to levels higher than one has been accompanied by negative spreads vis-à-vis the risk free rate, raising the issue as to whether providers are able to generate profits in the annuity business. As shown in Figure 4, the average annuity rate reported by providers was lower than the average risk-free rate in 1999, but since the early 2000s the average annuity rate has exceeded the risk-free rate, a result which is unusual by international comparison. For example, Brown et al (2001) compute the internal rates of return on US annuities and obtains rates ranging from 5.9 to 6.5 percent p.a., lower than the yields of 10 and 30-year Treasury bonds, which were 7.1 and 7.3 percent p.a. in the same period. James, Song and Vittas (2003) perform the same exercise for several countries and obtain similar results. ${ }^{14}$

Annuity providers can still achieve positive financial spreads and generate profits investing in higher yield paper, which is exactly what providers have been doing - the share of lower yield Government and Central bank bonds declined from 40 to 15 percent

\footnotetext{
${ }^{14}$ The annuity rate here is defined as the internal rate of return on the annuity contract, thus comparable with the results in Brown et al, and with the yield on financial instruments. Other researchers (Orszag (2001), Cannon and Tonks (2004)) define the annuity rate as the ratio of the annuity payment over the premium. This indicator is much higher than the internal rate of return on annuities - in Chile this indicator exceeds the annuity rate by more than 200 basis points. It is a useful indicator that can be easily computed and used to track the annuity rate (the two series are highly correlated), but is not directly comparable to the yield of financial instruments. The ratio of payments to the principal is only equal to the internal rate of return in the case of perpetuities or consols.
} 
of the portfolio in the past 10 years while the share of mortgage and corporate bonds increased commensurately. Figure 4 indicates that a portfolio of corporate bonds would have generated returns exceeding the annuity rate by 100-120 basis points in 2002-2005. However, this strategy implies excessive concentration of risks in one asset class. Moreover, providers also have to pay for brokers' commissions, cover their operating costs, make an allowance for several risks such a default risk, and generate an adequate return on equity. Therefore, both the MWRs and the spreads estimated for recent years indicate a situation that may not be sustainable.

An international comparison of MWRs estimated with a higher discount rate yields similar conclusions. As shown in Table 15, the average MWR for 2004 drops from 1.06 to 0.9 when it is computed with the corporate bond rate. However, MWRs for representative classes of annuities in Chile remain significantly higher than the corresponding averages for other countries, as shown in table 17 . This suggests thin margins for Chilean providers on a present value basis, possibly making some providers unable to cover all costs and risks and still generate a positive profit margin. It is possible that the high MWRs observed in recent years reflect aggressive pricing strategies by some providers and that MWRs computed with the risk-free rate will eventually decline to levels closer to one with the ongoing industry consolidation.

Figure 4

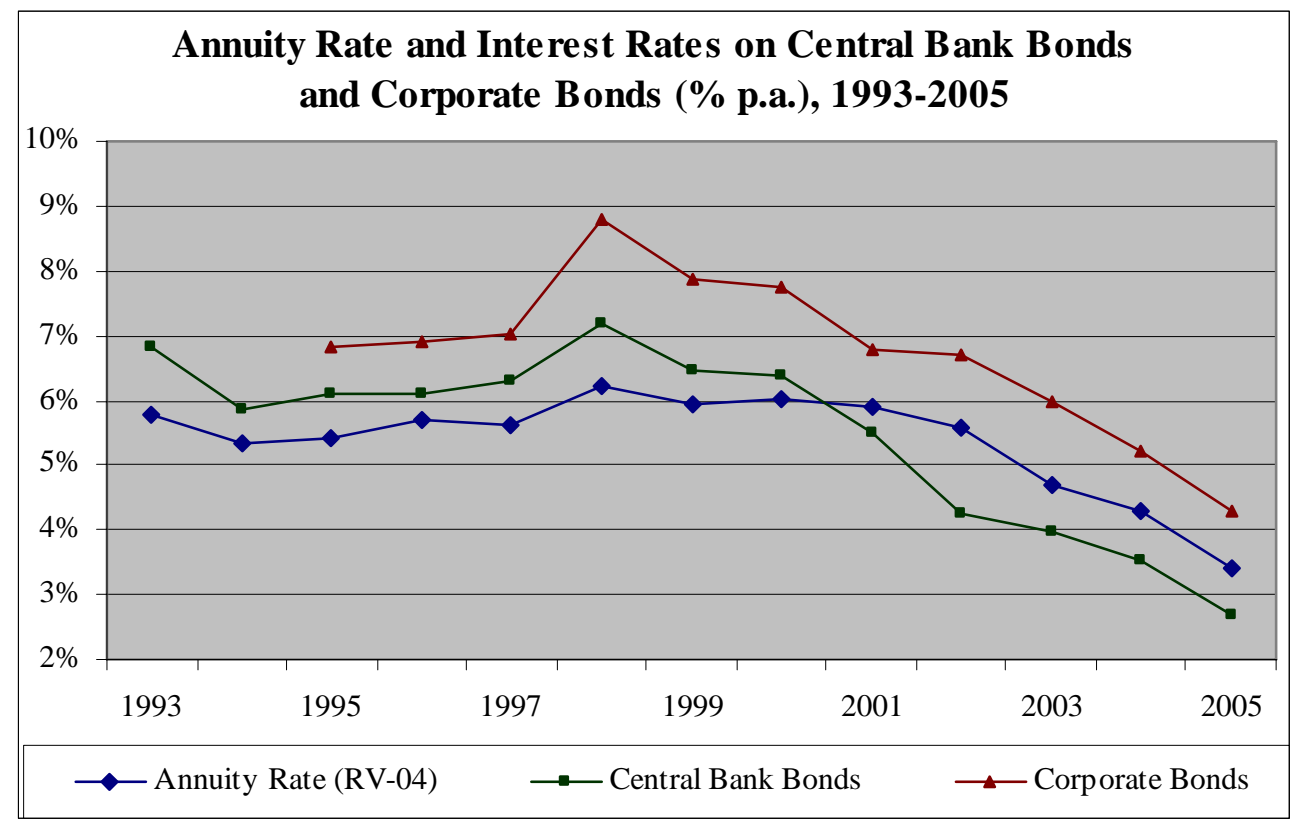

\subsection{Comparisons with Other Estimates for Chile}

This section compares the MWRs estimated in this study with those estimated by James, Iglesias and Martinez (2005), who compute MWRs using data on quoted annuities from 4 insurance companies in March 1999 and March 2003. The MWRs are calculated using 3 alternative mortality tables, 2 different discount rates, and 2 different premium levels. 
The mortality tables are the RV-85 and the RV-98 in period form, and the RV-98 in a cohort form using rates of mortality improvement from the Canadian Institute of Actuaries. The two discount rates used are the risk-free rate and the corporate bond rate. The MWRs are estimated for premiums of UF 1,000 and UF 4,000. Table 18 reproduces their MWRs for 1999 and 2003 while Table 19 reproduces our estimates for the same years to facilitate comparisons.

As shown in Tables 18 and 19, our MWRs computed with the risk-free rate for 1999 are roughly equal to those presented by James et al for joint annuities, only slightly higher in the case of single males age 65, and higher in the case of single females age 60 . The results are somewhat surprising, especially for single male and joint annuities, because the differences between the period RV-98 and the cohort RV-04 should lead to larger differences between MWRs. Moreover, our MWRs are estimated from the total universe of actual sales, while James, Iglesias and Martinez use a sample of quoted annuities from 4 companies. Since annuity sales tend to reflect the best quotes, MWRs based on sales should be higher than those estimated from quotes.

Table 18

Money's Worth Ratios for Chile Estimated by James et al for 1999 and 2003

\begin{tabular}{|c|c|c|c|c|c|}
\hline & March 1999 & \multicolumn{4}{|c|}{ March 2003} \\
\hline & $\begin{array}{c}\text { RV-98 Period } \\
\text { Risk-free rate } \\
\text { UF1,000 } \\
\text { Premium }\end{array}$ & $\begin{array}{c}\text { RV-98 Period } \\
\text { Risk-free rate } \\
\text { UF1,000 } \\
\text { Premium }\end{array}$ & $\begin{array}{c}\text { RV-98 Cohort } \\
\text { Risk-free rate } \\
\text { UF1,000 } \\
\text { Premium }\end{array}$ & $\begin{array}{c}\text { RV-98 cohort } \\
\text { Risk-free rate } \\
\text { UF4,000 } \\
\text { Premium }\end{array}$ & $\begin{array}{c}\text { RV-98 Cohort } \\
\text { Corp. bond rate } \\
\text { UF1,000 } \\
\text { Premium }\end{array}$ \\
\hline Male, 65 & 0.979 & 0.981 & 1.012 & 1.013 & 0.905 \\
\hline Male, 55 & - & 0.941 & 0.976 & 0.999 & 0.879 \\
\hline Female, 60 & 0.963 & 0.925 & 0.958 & 0.992 & 0.845 \\
\hline Female, 55 & - & 0.899 & 0.929 & 0.977 & 0.810 \\
\hline Joint & 1.000 & 0.977 & 1.008 & 1.025 & 0.883 \\
\hline
\end{tabular}

Source: James, Iglesias and Martinez (2005)

Table 19

Money's Worth Ratios for Chile Estimated by this Report, 1999 and 2003

\begin{tabular}{l|c|cc}
\hline & March 1999 & \multicolumn{2}{|c}{ March 2003 } \\
\hline & $\begin{array}{c}\text { RV-04 Cohort } \\
\text { Risk-free rate } \\
\text { Average }\end{array}$ & $\begin{array}{c}\text { RV-04 Cohort } \\
\text { Risk-free rate } \\
\text { Average }\end{array}$ & $\begin{array}{c}\text { RV-04 Cohort } \\
\text { Corporate bond rate } \\
\text { Average }\end{array}$ \\
\hline Male, 65 & 0.996 & 1.069 & 0.955 \\
Male, 55 & 0.981 & 1.049 & 0.897 \\
Female, 60 & 1.021 & 1.077 & 0.971 \\
Female, 55 & 0.994 & 1.049 & 0.905 \\
Joint & 0.998 & 1.050 & 0.892 \\
\hline
\end{tabular}

Source: Table 4

Our MWRs computed with the risk-free rate for 2003 are higher than those presented by James, Iglesias and Martinez for the same year, with the differences ranging from 3 to 10 percent. Again, the differences are larger in the case of females. These differences are more consistent with the differences between the mortality tables, especially regarding 
female mortality rates, as well as the differences between annuity sales and annuity quotes. However, it is noteworthy that our MWRs increase between 1999 and 2003 while the MWRs estimated by James, Iglesias and Martinez remain stable or even decrease. This stability of MWRs is at odds with the behavior of the risk-free rate annuity rate differential in the same period. As shown in Figure 4, the relation between the risk-free rate and the annuity rate would only be consistent with MWRs lower than one in 1999 and higher than one in subsequent years, including 2003.

The main conclusion of James, Iglesias and Martinez, that Chilean MWRs are high by international comparison and that Chilean annuitants have got a good deal for their money is the same as the one reached here, but their numbers probably underestimate the true MWRs in March 2003. In addition to the use of an outdated mortality table, it is possible that their results are also being affected by a small and non-representative sample of annuity quotes. The risk-free yield curve used for discounting is probably different and may be also contributing to the different results.

\section{Conclusions}

On any measure, the results in Chile indicate good value for consumers. In part, this can be explained by the larger supply of assets indexed to consumer prices in Chile, including higher yield indexed instruments such as mortgage, corporate, and infrastructure bonds. Rocha, Morales and Thorburn (2006) provide separate evidence that the annuity rate is positively correlated with the share of higher yield assets in the portfolios of providers, suggesting that MWRs are also positively affected by this factor. In other countries, providers are either exposed to inflation risk, due to the absence of indexed instruments, or can only access lower yield indexed instruments such as indexed government bonds.

The high MWRs may also reflect aggressive pricing behavior in a very competitive annuities market. It is interesting to note that the structure of MWRs suggests efficient risk differentiation - MWRs are higher for customers that present relatively lower reinvestment and mortality risk to the provider. That is, annuities with a shorter expected duration tend to have higher ratios than those with a longer duration. However, the overall levels of MWRs seem excessive, suggesting that providers may be either counting on future increases in interest rates, or deliberately accepting temporary losses to drive competitors out of the market and gain market share. Rocha, Morales and Thorburn (2006) provide separate evidence that the annuity rate increases with the level of competition, and decreases for larger firms with established market share, suggesting that the high degree of competition also explain the high MWRs.

The MWRs of the recent years probably cannot be sustained for a longer period, however, as they indicate very low spreads and profit margins and possibly losses in the annuity business for at least some companies in this period. The industry could absorb these losses, because of the strong capital buffer accumulated in the 1990s, and which was due to the introduction of a strict capital regulation early in that decade (Rocha and Thorburn (2006)). However, the continuation of aggressive pricing strategies could lead 
to further erosion of capital. Therefore, some market adjustments should be expected, leading to some decline in money's worth ratios.

Although individual annuitant characteristics explain a significant share of variations in MWRs, a large share of these variations remains unexplained. The dispersion of MWRs has decreased since March 1999, reflecting the threat imposed by the submission of the draft Pension Law to Congress. There is evidence, albeit limited, that dispersion of MWRs declined further in March 2005, possibly reflecting the approval and implementation of the Pensions Law in 2004, especially the new electronic quotation system. More research on MWRs is merited, to confirm whether the new quotation system has indeed resulted in the elimination of price inefficiencies and a reduction in price dispersion. More generally, the new system is an important and welcome innovation, and its outcomes should be closely and frequently monitored by regulators in Chile and other countries. 


\section{References}

Benjamin, B., and J. H. Pollard (2001), The Analysis of Mortality and Other Actuarial Statistics, Institute of Actuaries and Faculty of Actuaries, London.

Brown, Jeffrey, Olivia S. Mitchell, and James M. Poterba (2001) “The Role of Real Annuities and Indexed Bonds in an Individual Accounts Retirement Program,” in Brown, Jeffrey, Olivia S. Mitchell, James M. Poterba and Mark J. Warshawsky, The Role of Annuity Markets in Financing Retirement, MIT Press, Cambridge, Massachusetts.

Olivia S. Mitchell, James Mr. Poterba and Mark J. Warshawsky (2001)

"Taxing Retirement Income: Nonqualified Annuities and Distributions from Qualified Accounts,” in Brown, Jeffrey R., Olivia S. Mitchell, James M. Poterba and Mark J. Warshawsky, The Role of Annuity Markets in Financing Retirement, MIT Press, Cambridge, Massachusetts.

Brown, Jeffrey, Olivia S. Mitchell, James M. Poterba and Mark J. Warshawsky (2001), The Role of Annuity Markets in Financing Retirement, MIT Press, Cambridge, Massachusetts.

Cannon, Edmund and Ian Tonks (2004) “U.K. Annuity Rates, Money’s Worth and Pension Replacement Ratios 1957-2002.” The Geneva Papers on Risk and Insurance. Vol. 29, no. 3, 371-393, July.

Dus, Ivica, Raimond Maurer and Olivia S. Mitchell (2003) "Betting on Death and Capital Markets in Retirement: A Shortfall Risk Analysis of Life Annuities versus Phased Withdrawal Plans,” MRRC Working Paper, WP2003-063.

Finkelstein, Amy and James Poterba (1999). "The Market for Annuity Products in the United Kingdom“. NBER Working Paper no. 7168. National Bureau of Economic Research. Cambridge, Mass.

James, Estelle, Guillermo Martinez and Augusto Iglesias, (2005) “The Payout Stage in Chile: Who Annuitizes and Why?” Unpublished Manuscript. Guillermo Martinez and Augusto Iglesias (2004) "Postponed vs. Early

Access to Individual Accounts and the Fiscal Implications of the Minimum Pension Guarantee in Chile,” paper presented at the AEA meeting, January.

, Xue Song and Dimitri Vittas (2003), “Annuity Markets Around the World Money’s Worth to Annuitants and How do Insurance Companies Cover It?”

Liu, Sheen, Howard Qi and Chunchi Wu (2004) “Taxes, Default Risk and Corporate 
Ministry of Labor (2004) Primera Encuesta de Protección Social (First Survey of Social Protection). Santiago de Chile.

Mitchell, Olivia S., James M. Poterba, Mark J. Warshawsky and Jeffrey R. Brown (2001) "New Evidence on the Money's Worth of Individual Annuities," in Brown, Jeffrey R., Olivia S. Mitchell, James M. Poterba and Mark J. Warshawsky, The Role of Annuity Markets in Financing Retirement, MIT Press, Cambridge, Massachusetts.

Orszag, Mike (2001) “Retirement Income Decisions,” Paper presented at IFID Conference, Fields Institute of Mathematical Sciences, Toronto, September.

Rocha, Roberto, Marco Morales, and Craig Thorburn (2006) “An Econometric Analysis of the Annuity Rate in Chile,” Unpublished manuscript. The World Bank.

Rocha, R., and C. Thorburn (2006), Developing Annuities Markets: The Experience of Chile. The World Bank. Washington DC. 